\title{
Examination of Factors Affecting Youths' Entrepreneurial Intention: A Cross-Sectional Study
}

\author{
Muhammad Azrin Nazri" ${ }^{*}$, Haleemath Aroosha ${ }^{2}$, Nor Asiah Omar ${ }^{3}$ \\ ${ }^{1}$ Islamic Science University of Malaysia (USIM), Malaysia \\ ${ }^{2}$ Asia Pacific University of Technology \& Innovation (APU), Malaysia \\ ${ }^{3}$ National University of Malaysia (UKM), Malaysia \\ muhdazrin@usim.edu.my, haleematharoosha@gmail.com,norasiah@ukm.edu.my
}

\begin{abstract}
This study aims to examine the predictive effect of enterprise education, perceived social norms, entrepreneurial motivations, perceived structural support and innovativeness on entrepreneurial intention. A total of 150 useable responses were collected among young people living in the capital of Maldives, Male'. A cross-sectional quantitative survey was carried out by using a structured questionnaire. A relevant statistical analytical such as regression analysis was used to test the hypotheses set forth in this study. The descriptive results showed that male respondent is slightly more than female respondent which is consistent with the 2014 census of Maldives showing male population in the country is slightly higher than female. The majority of the respondents participated in this survey are from the age group of 18-22 years old. The main finding of the study showed enterprise education, perceived social norms, entrepreneurial motivations and innovativeness have a positive and significant relationship towards entrepreneurial intention. However, perceived structural support has no significant relationship towards entrepreneurial intention. In this study it was also found that enterprise education was the most significant predictor of entrepreneurial intention followed by entrepreneurial motivation, innovativeness and perceived social norms. This finding makes a considerable contribution to the existing literature on factors influencing entrepreneurial intentions among youth in Maldives. The implication and limitations of the study are also discussed.
\end{abstract}

Keywords: Enterprise education, Perceived social norms, Perceived structural support, Entrepreneurial Motivation, Innovativeness, Entrepreneurial intention

\section{Introduction}

Entrepreneurship is defined as "the activities involved in owning and managing a business." Creation of such new business has been the main reason for the success in many developing economies such as Swaziland, Bangladesh, Bhutan and Maldives (Beaugrand, 2004). Dash and Kaur (2012) define youth as a person between 18-35 years of age. The belief that entrepreneurship and youth entrepreneurship are interchangeable has led to some researchers focusing on "entrepreneurship" as a general concept. Basically, youth entrepreneurship plays a significant role in alleviating youth unemployment and accelerating economic development through their input of new ideas for profitable ventures. The future working environment will depend on the creativity and individuality of the young (Henderson and Robertson, 2000). As a result, youth entrepreneurship has gained the interest of researchers in determining the factors that influence their entrepreneurial intentions. According to the studies conducted on youth entrepreneurship, young people consider starting their own businesses mainly due to the freedom of autonomy (Mitra, Abubakar and Sagagi, 2011). Krueger (2008) believes that intentions lead to behaviour. Hence, a high intention among youth to start their own business will ensure future ventures. Therefore, it is important to analyze the factors that influence the intention of starting own business so that competitive young entrepreneurs can be developed (Schwarz et al., 2009). A number of studies have been done to analyze different factors that influence entrepreneurial intention. Most of these studies analyzed social norms, attitudes and behavioral controls as the main factors. However, recent studies started to include more variables to broaden factors that influence entrepreneurial intentions. Luthje and Frankle (2003) combined both personality traits as well as external environmental factors which enhanced the previous studies done on this topic. Later Schwarz et al. (2009) included education as a variable in his studies on entrepreneurial intention.

Although, most of these studies were conducted on a western perspective, it should be noted that entrepreneurial intentions vary sharply from country to country (Schoof, 2006). Moreover, despite the importance of youth entrepreneurship, this field is constrained by a severe lack of sound evidence (Schoof, 2006). There is also little understanding of the factors that affect young people to become entrepreneurs (Souitaris, Zerbinati and Al-Laham, 2007). Thus, youth entrepreneurship remains as a topic that lacks broad 
research even though it is recognized as an important aspect to the economic development. According to Baporikar (2014), the main reason for the increase in importance given to youth entrepreneurship is due to the rise in the number of unemployed youth. In Maldives, the rate of unemployed youth in 2013 is $26.5 \%$ and the number is on the rise; hence youth entrepreneurship is believed can bring a positive impact on this matter (Quandl, 2015). Basically, youth entrepreneurship gained the attention of Maldivians with the launch of "Get Set-Maldives Youth Entrepreneurship Program" in 2014. Under this program, MVR200 million (US\$12.9 million) worth of loans will be provided to youth who wants to start their own business (Naish, 2014). The main reason for this initiative was to reduce the number of unemployed youth taking the road of crimes. However, the success of the programme depends on the level of entrepreneurial intention among youth. Koe et al. (2012) mentioned that entrepreneurial intention determinants vary between cultures and countries. There are even some contrasting views that too much emphasis is given to developed nations when studying entrepreneurial intention (Eijdenberg and Masurel, 2013). Therefore, this study aims to investigate factors that influence entrepreneurial intention of young people in developing country. Since youth entrepreneurship is particularly a new concept for Maldivians (Villarino, 2015), this study will investigate whether enterprise educations, perceived social norms, perceived structural support, entrepreneurial motivations, innovativeness influence entrepreneurial intention among youth in Maldives.

\section{Literature Review}

Generally, Mobaraki and Zare (2012) defined intentions as the proximal cognitive state that is temporally and causally prior to the intended behaviour. Specifically, Thompson (2009) defines entrepreneurial intention as a self-acknowledged conviction by a person that they intend to set up a new business venture and consciously plan to do so at some point in the future. Other researchers define entrepreneurial intention as the readiness to start a business, with risk-taking propensity, locus of control and attitudes towards self-employment as predictors (Luthje and Frankle, 2003). An individual's intention towards entrepreneurship depends on the desirability of the action such as the attractiveness of becoming an entrepreneur and the level of confidence that the action will be realized. Moreover, the intention can be formed by the people's capability to act according to their own decision (Solesvik, Westhead and Matlay, 2014). Luthje and Frankle (2003) carried out studies to investigate the entrepreneurial intention. They revealed that attitude towards self-employment is positively related with contextual factors (perceived support); internal factors (motivation) and enterprise education. Therefore, it can be said that the individuals, in this case the youth in Maldives, should be given enough support, motivation and required skills to enhance their attitude towards starting up own business rather than fully depending on a job in this economy where it is hard to get one.

Educational institutes have improved the business curriculums aimed at increasing the awareness on entrepreneurship and developing business skills, creativity, imagination and mind set to support selfemployment activities (Frank, 2007). Studies conducted on enterprise education showed that individuals who are exposed to knowledge about starting-up businesses are more likely to take up self-employment opportunities (Frank, 2007). Therefore, it is essential to provide entrepreneurship education and skill development opportunities in order to foster intention for entrepreneurial activities. A study by Wang and Wong (2004) indicated that lack of entrepreneurship knowledge from academic institutions acted as barrier for many students from starting their own business. Other researchers came to the same conclusion that educational institutes help in fostering entrepreneurial traits among individuals by developing their innovation skills (Ibrahim and Soufani, 2002). According to a report by Organization and Economic Cooperation \& Development (OECD) in 2013, the effect of any kind of entrepreneurship education on the development of skills varies among different cultures. It showed that the individual's entrepreneurial intention is fostered through education in several countries for examples in Brazil, India and Portugal. However, in countries such as Japan and UK have a low percent of individuals who believe that education can foster entrepreneurship. Thus, it can be said that the role of enterprise education and how it affects entrepreneurial intention differs across countries. Global Education Initiative (GEI) report by World Economic Forum (2009) stated that entrepreneurship education significantly influences attitudes, skills and culture. In addition, teaching these attitudes and behaviours from youth until adulthood is essential for entrepreneurial growth. Therefore, it is important to examine whether education influences entrepreneurial intention among young Maldivians. 
Social norms are the individual's belief about the pressures from society and close people in making a certain decision. In some countries entrepreneurship is encouraged while in others it is not seen as a good career choice (Global Entrepreneurship Monitor, 2014). According to Solesvik (2013), the opinions of important people such as family, friends, teachers and the society as a whole shape the entrepreneurial intentions of a person. These could be the start-up problems arising from family disapproval or social disapproval towards entrepreneurship. Engle, Schlaegel and Delanoe (2011) conducted a research about the social norms affecting entrepreneurship intention among 14 different countries. The result showed that three factors under social group, family, friends and role models have a positive influence on the entrepreneurial intent. The study focused on the degree of encouragement from these social groups and the importance of their opinion on the decision to start own business. Thus, it is also important to conduct similar study among young Maldivian. Mueller and Thomas (2001) evaluated that the valuation of a career choice in the society has a significant impact on the engagement in that career. Other studies also exerted that socio-cultural values, attitudes and perception towards entrepreneurial activities led to the development of own venture creations (Vaillant and Lafuente, 2007). Social predictors of entrepreneurial intention generally focuses on desirability of entrepreneurship as a career choice, level of respect given by society for entrepreneurs and barriers associated with such a decision (Abebe, 2012).

Perceived structural support is mainly influenced by the economic and political mechanisms that form opportunities and barriers to the entrepreneurs (Turker and Selcuk, 2009). These include elements such as the opportunity to start-up business, accessibility to finance, state laws and lastly encouragement from public, private and non-governmental organizations. Schoof (2006) carried out studies on the perceived structural support as a factor influencing the youth entrepreneurship. These studies revealed that access to finance, administrative, regulatory framework and business assistance acts as barriers in starting own business. The encouragement from the economy and government is significant in shaping the perception of youth towards self-employment. Favourable support from the government towards financial access and regulatory framework will enhance youth entrepreneurship and develop the economy. Delanoë (2013) categorizes the support as "hard" when it comes in the form of loan guarantee schemes and "soft" when it is advisory assistance. These support forms can positively influence the youth in setting up their own business. The high financial accessibility will encourage them to start enterprises. Turker and Selcuk (2009) conducted a research to investigate the factors affecting entrepreneurial intention and found that structural support is significant.

Almobaireek and Manolova (2012) defined entrepreneurial motivations as "expectations and beliefs about the personal impacts of outcomes of starting a business". They have also conducted a research on the motivational factors that influence an individual to start their own business. These factors include financial gains, higher social position, gaining experience, achievement and reaching a personal vision. This study revealed that the more motivational factors an individual have the greater the likelihood of expressing entrepreneurial intention. Eijdenberg and Masurel (2013) describe the entrepreneurial motivations as "pull" and "push" factors. "Pulled" entrepreneurs are individuals who start their own business due to personal unforced desires. On the other hand, "pushed" entrepreneurs are pushed to start their own business due to dissatisfaction with the current position or any other reason that is unrelated to the individual's entrepreneurship characteristics. Shane et al. (2012) conducted a study on the entrepreneurial motivators which has been referred to in many other researches. The author found that the most significant factors affecting entrepreneurial motivations are the need for achievement, a person's locus of control, desire for independence, vision, passion, drive, a person's goal setting and self-efficacy. Innovativeness is the ability to introduce and apply ideas, processes, products and procedures that are new (Altinay et al., 2012). It is about an individual being open to new ideas, changes and making independent decisions. Innovativeness has been increasing in importance in many studies which shows the importance of it towards entrepreneurship. Many studies reported that entrepreneurs are more innovative than non-entrepreneurs (Gürol and Atsan, 2006).

According to a study done by Gürol and Atsan (2006), there is significant relationship between innovativeness and entrepreneurial intention. Another study done by Gurel et al. (2010) on the innovativeness of British and Turkish students, showed same positive results. In addition, Mueller and Thomas (2001) recognized innovativeness as an important characteristic toward starting own business. In 
many of the previous entrepreneurship studies, researchers describe entrepreneurs as "innovators". Therefore, in view of the preceding discussion, the following hypotheses are proposed:

H1: There is a relationship between enterprise education and entrepreneurial intention.

H2: There is a relationship between perceived social norms and entrepreneurial intention.

H3: There is a relationship between perceived structural support and entrepreneurial intention.

H4: There is a relationship between entrepreneurial motivation and entrepreneurial intention.

H5: There is a relationship between innovativeness and entrepreneurial intention.

Conceptual Model: A comprehensive literature review shows a lack of empirical studies that examine the impact of enterprise educations, perceived social norms, perceived structural support, entrepreneurial motivations, and innovativeness on entrepreneurial intention among youth in Maldives. Hence, a conceptual model was proposed as shown in Figure 1. In this model, all five factors (enterprise educations, perceived social norms, perceived structural support, entrepreneurial motivations, and innovativeness) influence entrepreneurial intention (H1-H5).

Figure 1: Research Model

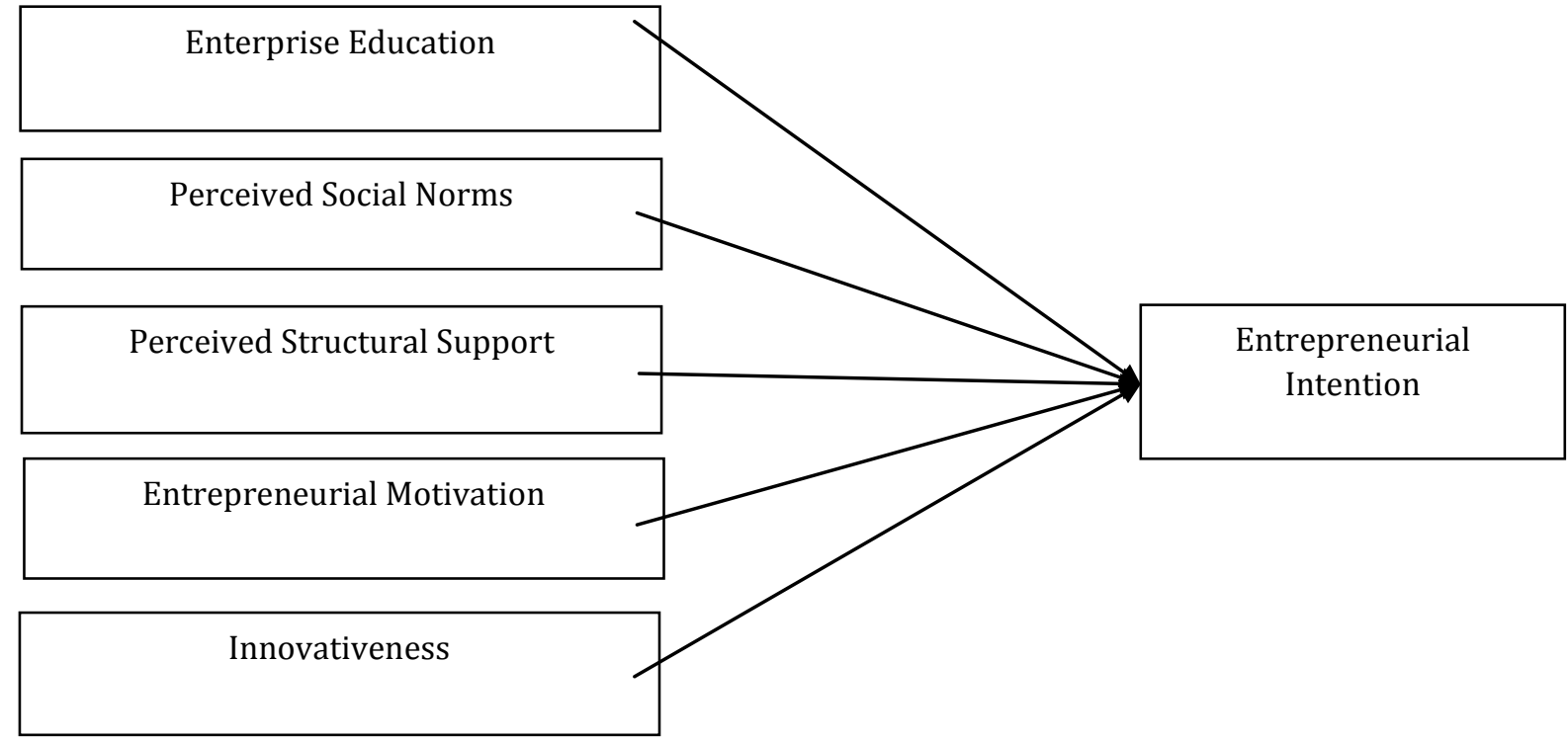

\section{Methodology}

Data collection and sample: The target population of this research is young people living in the capital of Maldives, Male'. The capital city is chosen as more than one-third of the population of Maldives lives here which consists of people from various parts of the country (Anees, 2014). Moreover, in Maldives, the number of unemployed youth in 2013 is 26.5\% (Quandl, 2015). Thus, the government is taking initiatives to reduce the number of unemployed youth taking the road of crimes. The youth entrepreneurship gained the attention of Maldivians with the launch of "Get Set-Maldives Youth Entrepreneurship Program" during the end of 2014. Under this program, MVR200 million (US\$12.9 million) worth of loans will be provided to youth who wants to start their own business (Naish, 2014). Even though the loans are provided, the success depends on the level of entrepreneurial intention among youth. The respondents of the study are youth whose age is between 18 and 35 years old. Dash and Kaur (2012) defines youth as a person between 18-35 years of age. A questionnaire survey was developed to obtain the responses about their opinions on factors motivating them to be entrepreneurs. All measurement items were adapted from past studies (refer to table 1). Five-point Likert scales anchored by two sides of opinions from "strongly disagree" to "strongly agree" were applied.

A cross-sectional research design was employed because the data was collected at a single point in time (Sekaran and Bougie, 2010). The cross-sectional design was chosen because it saves time and cost effective which meets the study's requirements (Sekaran and Bougie, 2010). This study employed the quantitative research approach where it is widely used in social sciences (Sekaran, Robert and Brian, 2001). To 
substantiate the appropriateness of the items used in the study context, three experienced practitioners were invited to assess the content validity of each item with respect to the definition and study context. Slight changes were made following comments and suggestions without substantially altered the questionnaire. This study used convenience sampling and the data were collected by using self-administered questionnaires distributed via the drop and collect technique. The researcher employed convenience sampling method where the respondents were chosen according to their accessibility. According to Sekaran and Bougie (2010) convenience sampling method is very fast, convenient and less costly. Of the 250 distributed questionnaires, 150 respondents completed and returned the questionnaires, representing a response rate of 60 per cent.

Table 1: Measurements

\begin{tabular}{|c|c|c|}
\hline Variables & Source of items & Items \\
\hline $\begin{array}{l}\text { Entrepreneurial } \\
\text { intention }\end{array}$ & $\begin{array}{lll}\begin{array}{l}\text { Dinis } \\
(2013)\end{array} & \text { et } & \text { al. }\end{array}$ & $\begin{array}{l}\text { I am ready to do anything to start my own business } \\
\text { My professional goal is to start my own business } \\
\text { I will make every effort to start and run my own firm } \\
\text { I am determined to create a firm in the future } \\
\text { I have the intention to start a firm someday }\end{array}$ \\
\hline $\begin{array}{l}\text { Enterprise } \\
\text { education }\end{array}$ & $\begin{array}{lr}\text { Keat, } & \text { Selvarajah } \\
\text { and } & \text { Meyer } \\
(2011) & \end{array}$ & $\begin{array}{l}\text { University/school is an ideal place for me to learn about starting a } \\
\text { business } \\
\text { More education programs will help me to start my own business } \\
\text { Entrepreneurial courses/subjects should be made compulsory in } \\
\text { order to stimulate entrepreneurial spirit } \\
\text { We are actively encouraged to pursue business ideas in the } \\
\text { university/school } \\
\text { A creative university/school environment inspires me to develop } \\
\text { ideas for new business }\end{array}$ \\
\hline $\begin{array}{l}\text { Perceived social } \\
\text { norms }\end{array}$ & $\begin{array}{l}\text { Heuer and } \\
\text { Kolvereid, } \\
2014) ; \quad \text { Liñán, } \\
\text { Urbano and } \\
\text { Guerrero (2011) }\end{array}$ & $\begin{array}{l}\text { My family will always give me support if I wanted to start my own } \\
\text { business } \\
\text { My closest friends will always give me support if I wanted to start } \\
\text { my own business } \\
\text { Most people in my country consider it acceptable to start own } \\
\text { business } \\
\text { The culture in my country is highly favorable towards } \\
\text { entrepreneurial activity } \\
\text { The entrepreneur's role in the economy is generally valued in my } \\
\text { country }\end{array}$ \\
\hline $\begin{array}{l}\text { Perceived } \\
\text { structural } \\
\text { support }\end{array}$ & $\begin{array}{l}\text { Turker and } \\
\text { Selcuk (2009) }\end{array}$ & $\begin{array}{l}\text { Entrepreneurs in Maldives are encouraged by private, public and } \\
\text { non-governmental organizations } \\
\text { The economy of Maldives provides many opportunities for } \\
\text { entrepreneurs } \\
\text { Getting loans is quite easy for entrepreneurs in Maldives } \\
\text { Rules and regulations in Maldives are favorable to running own } \\
\text { business }\end{array}$ \\
\hline $\begin{array}{l}\text { Entrepreneurial } \\
\text { motivations }\end{array}$ & $\begin{array}{l}\text { Eijdenberg and } \\
\text { Masurel (2013); } \\
\text { Almobaireek } \\
\text { and Manolova } \\
(2012)\end{array}$ & $\begin{array}{l}\text { Financial gain makes me want to start my own business } \\
\text { Lack of employment opportunities in Maldives encourages me to } \\
\text { start my own business } \\
\text { I want to start my own business so that I can achieve more in life } \\
\text { I want to create my own business so that I can be independent }\end{array}$ \\
\hline
\end{tabular}


Innovativeness Dinis et al. I like changing the way things are done

(2013) While others see nothing unusual in the surroundings, I am able to perceive opportunities for business I am able to get around difficulties through strokes of imagination and resourcefulness

I believe there are always new and better ways of doing things I find it easy to come up with new, wild or even crazy ideas

\section{Findings}

A total of 157 questionnaire respondents were collected within the capital city of Maldives, Male'. Preliminary analyses were conducted to provide information about the characteristics of respondents. There are about $52.87 \%$ of male respondents and $47.13 \%$ is female. According to the preliminary result of census 2014 in Maldives, $50.75 \%$ is male and $49.25 \%$ is female (National Bureau of Statistics, 2015). It can be said that the male population in Maldives is slightly higher than female. As a result, the respondents of this questionnaire reflect this difference in distribution as well. Most of the respondents from this survey are of the age group 18-22 years old which is $42.04 \%$ of the total respondents. The second largest group is of $23-27$ year olds which consist of $35.03 \%$ of the respondents. The age group of $28-34$ year old shows a much lower percentage of $22.29 \%$. There were no missing values as the measurements were taken during the questionnaire distribution to retain full respondent answers. The normality of distribution was examined with the analysis of skewness and kurtosis of the data. The skewness and kurtosis of the data shows a value close to zero which represents normality distribution (Tabachnik and Fidell, 2001). A reliability test was conducted on the dataset to ensure that all items to be used for the survey are reliable before testing the hypothesis. Results in Table 2 shows the Cronbach's Alpha value for all variables are higher than 0.7. According to Nunnally (1978), if the reliability coefficient has a minimum value of 0.70 then it is regarded as 'adequate' in most research situations.

Table 2: Reliability Testing

\begin{tabular}{l|l}
\hline Constructs & Cronbach's Alpha \\
\hline Entrepreneurial Intention & 0.941 \\
Enterprise Education & 0.775 \\
Perceived Social Norms & 0.772 \\
Perceived Structural Support & 0.890 \\
Entrepreneurial Motivations & 0.817 \\
Innovativeness & 0.876 \\
\hline
\end{tabular}

Table 3 presents results of a multiple regression analysis used to evaluate the strength of the proposed relationship. Five hypotheses were formulated and all the variables were retained after performing the reliability and validity testing. Multiple regression prediction models follows the guidelines by Hair et al. (2009) to test the impact of enterprise education, perceived social norms, perceived structural support, entrepreneurial motivations and innovativeness with entrepreneurial intention as the dependent variable. The multiple regression analysis showed an $\mathrm{R}$ square of .461 which means about $46.1 \%$ of dependent variable is explained by all the independent variables used in this study.

Table 3: Regression analysis results-Model Summary

\begin{tabular}{llllll}
\hline Model & $\mathbf{R}$ & R Square & Adjusted R Square & $\begin{array}{l}\text { Std. Error of the } \\
\text { Estimate }\end{array}$ \\
\hline 1 & $.679^{\mathrm{a}}$ & .461 & .443 & .78218 \\
\hline
\end{tabular}

a. Predictors: (Constant), I, PSS, EE, EM, PSN

Anova

\begin{tabular}{|c|c|c|c|c|c|}
\hline Model & & Sum of Squares df & Mean Square & $\mathbf{F}$ & Sig. \\
\hline 1 & Regression & 78.858 & 15.772 & 25.779 & $.000^{\mathrm{b}}$ \\
\hline
\end{tabular}




\begin{tabular}{llll} 
Residual & 92.382 & 151 & .612 \\
Total & 171.240 & 156 & \\
\hline
\end{tabular}

a. Dependent Variable: Entrepreneurial Intention

b. Predictors: (Constant), I, PSS, EE, EM, PSN

\section{Coefficients}

\begin{tabular}{llll}
\hline Factors/determinants & $\begin{array}{l}\text { Standardized } \\
\text { Beta Coefficients }\end{array}$ & $\mathbf{t}$ & Sig. \\
\hline (Constant) & & 2.456 & .015 \\
Enterprise Education (EE) & .312 & 4.254 & .000 \\
Perceived Social Norms (PSN) & .157 & 2.047 & .042 \\
Perceived Structural Support (PSS) & -.051 & -.726 & .469 \\
Entrepreneurial Motivations (EM) & .253 & 3.557 & .001 \\
Innovativeness (I) & .211 & 2.804 & .006 \\
\hline$F_{(5,156)}=25.78, R^{2}=0.461$, Adj. $R^{2}=0.443$ & & & \\
Dependent Variable: Entrepreneurial Intention & & & \\
\hline
\end{tabular}

The result showed that enterprise education, perceived social norms, entrepreneurial motivations and innovativeness have a positive and significant relationship towards entrepreneurial intention $(\beta=.312$, $\mathrm{p}<0.01 ; \beta=.157, \mathrm{p}<0.05 ; \beta=.253, \mathrm{p}<0.01 ; \beta=.211, \mathrm{p}<0.01)$ respectively. However, perceived structural support has negative influence as well as no significant relationship towards Entrepreneurial Intention. $(\beta=-$ $.051, \mathrm{p}>0.05)$. This concluded that perceived structural support did not influence the entrepreneurial intention among Maldivian Youth. These results provide support for H1 (a significant positive relationship between enterprise education and entrepreneurial intention), H2 (a significant positive relationship between perceived social support and entrepreneurial intention), $\mathrm{H} 4$ (a significant relationship between entrepreneurial motivation and entrepreneurial intention), and H5 (a significant positive relationship between innovativeness and entrepreneurial intention) but not for H3 (relationship between perceived structural support and entrepreneurial intention). In addition, this study also found that enterprise education becomes the most significant predictor of entrepreneurial intention followed by entrepreneurial motivation, innovativeness and perceived social norms.

Discussion: The results from this survey show enterprise education has a significant relationship towards entrepreneurial intention. This indicates that in Maldives, youth who are more exposed to entrepreneurship education have a high intention of starting own business. They believe that their business knowledge can be improved through entrepreneurship targeted curriculums and by providing a study environment that supports creative ideas. Frank (2007) stated that individuals who are exposed to business knowledge are more likely to start their own business. Moreover, educational institutes help in fostering entrepreneurship traits (Ibrahim and Soufani, 2002). The finding is also consistent with prior studies that explored entrepreneurship education can develop a person's level of self-efficacy (Wilson et al., 2007). In addition, students participated in entrepreneurship education have shown more intentions towards starting their own business (Noel, 1998). This is because entrepreneurship education will develop a vision among students to start their own business with innovation (Wilson, 2007). Perceived social norms also showed a significant relationship towards entrepreneurial intention. This denotes that more support from family, friends and the society can motivate Maldivian youth to go into a career as an entrepreneur. This is because the encouragement from people close to an individual affects the motivation to go into certain career path. This result is consistent with previous studies done by Engle et al. (2010) who exerted the social norm variable appeared to be significant predictor of entrepreneurial intent. Other researchers stated that social group, family, friends and role models have a positive influence on entrepreneurial intention after conducting a research among 14 different countries (Engle, Schlaegel and Delanoe (2011). In addition, Mitchell (2002) reported that entrepreneurial intention differs across cultures hence it can be concluded that Maldivian culture is favourable towards youth starting their own business.

The third factor that had a significant relationship towards entrepreneurial intention is entrepreneurial motivation. This implies that the youth in Maldives are more willing to start their own business if there are 
good returns such as financial gain and independence. Previous research conducted by Almobaireek and Manolova (2012) supporting the current results where if an individual has more motivators, that person is more likely to choose entrepreneurship. Baumol (1990) suggested that entrepreneurs are motivated by the reward structure in the economy where a new venture initiation focuses on the usefulness, utility, or desirability of an entrepreneurial career. Other researcher mentioned the economic decision is based on the expected net present benefits of entrepreneurship relative to the expected gains from wage labour (Campbell, 1992). Praag and Cramer (2001) found that people would become entrepreneurs if the expected rewards surpass the wages of employment. This is because expected rewards depended on assessments of individual ability and attitudes towards risk and perceptions of entrepreneurial feasibility. Moreover, the choice between employment and self-employment changes according to the individual's age (Levesque et al., 2002).

Innovativeness also showed a significant relationship towards entrepreneurial intention among youth in Maldives. This states that the more innovation capability an individual possess the more possibility of going towards self-employment. Youth especially will have more innovation capability hence it has a positive impact on entrepreneurship. This result is in line with Gürol and Atsan (2006) who states that entrepreneurs are more innovative than non-entrepreneurs and that there is in fact a positive relationship between innovativeness and entrepreneurial intention. Stewart et al. (2003) argue that innovation is inherent in the role of entrepreneurship and it can separate "entrepreneurs" from "managers". Other researcher found a close relationship between innovativeness and venture performance (Utsch and Rauch, 2000). Perceived structural support was not rejected and showed no significant relationship between this factor and entrepreneurial intention among youth in Maldives. Even though some previous research found that there is a significant relationship between these two factors, it should be noted that this relationship does not exist in Maldives. Moreover, most of the previous researches were conducted in developed nations while Maldives is a developing nation (Eijdenberg and Masurel, 2013). Hence, these differences could have contributed to this factor into not having an impact on entrepreneurial intention. In addition, as youth entrepreneurship is a new concept in Maldives, youth may not be aware about the government or organizational support available to them (Villarino, 2015).

\section{Implications and Conclusion}

This research has achieved its objectives in analyzing the factors that influence the youth of Maldives to start their own business. Youth entrepreneurship is new in Maldives; hence this research helps to investigate the entrepreneurship studies based on a new culture and environment. The result from this study showed that enterprise education has the highest impact on the youth of Maldives. Although the Getset program designed by the Maldivian government includes business training program for future entrepreneurs, if the youth are not encouraged to take initiative in such activities, it will not provide any benefit (Getset.mv, 2015). Instead of only creating a program, the government should provide more support. As youth entrepreneurship is comparatively new in Maldives, it is essential that the training and creativity building starts from a very young age. The teaching curriculum needs to be revised so that the students are given the chance to build their creativity. More extra-curricular activities could be introduced for students who are interested in actively participating in the economy rather than pushing them to towards a certain white collar profession. For example, a club within the school that gives the chance for students get to create their own company and plan investments would actually increase the practical knowledge of the future youth on what they can expect when they initially start a business. Events and activities in colleges and schools should be frequently held that give opportunities for youngsters to present their business ideas to the public which could actually help them to get investors.

Although structural support did not show a significant relationship towards entrepreneurial intention in this study, it still can be considered as an important influence. The result could have been due to the youth being unaware of the structural support provided by the government and society in Maldives. Therefore, more exhibitions, promotions and entrepreneurship programs need to be conducted within the country and not just in the capital city. Youth need to be able to understand that government loans and agencies are there to help the future young entrepreneurs. In addition, as the women have less encouragement from the culture, more social awareness is needed. The male respondents do not have a high influence from social values such as family, friends and society as it had on female respondents. More social awareness and programs need to 
be conducted by the government agencies so that no gender discrimination exists that might discourage women to be entrepreneurs. Women entrepreneurs should be given the chances and opportunities from the government as what have been provided to men. Social encouragement from the society towards youth entrepreneurship, especially women, needs to be improved. Although women are given the chance for selfemployment in Maldives, the results show that there is some hesitant from this gender due to the society values. In addition, it was also found that enterprise education has a high impact on women as well. Therefore, the government should establish more activities to provide structural support as well as creativity building programs designed especially for women.

Other factors such as innovativeness and motivators also showed a significant relationship in entrepreneurial intention among youth in Maldives. More programs and activities should be conducted within the education curriculum at school as well as outside school compound so that it helps students to develop their innovation capability. Some youth only know about the risks and failures about starting own business and less aware about the benefits and how to overcome the risks. Innovation building is very essential to encourage youngsters to create innovative business ideas that can succeed in the Maldivian culture. There are some limitations that suggest caution in assessing the findings. First, limitations related to the sample size. The sample size used for this study is 150 respondents. In addition, the sample was limited to the capital city of Maldives, Male'. According to Sekaran and Bougie (2010), cost and time constraints determines the sample size and as this was a cross-cultural research, a small sample size was selected. Therefore, this study represents a small part of the total population which may not accurately represent the whole youth in Maldives.

Moreover, a research by GEM (2013) states that perception of entrepreneurship as a career choice differs between regions. Although the respondents were selected from the capital city to represent the population of the Maldives, the difference in culture and other environmental factors can influence the entrepreneurial intention in other countries. Hence, the result of this research cannot be generalized as a whole to represent the intention in other regions. The variables used in this study do not cover all the factors that can contribute to the entrepreneurial intention. The results show that the R-square is 0.461 which means $46 \%$ variables contribute to the entrepreneurial intention. Hence, the variables that are not examined in this study might contribute to the finding (influencing the entrepreneurial intention), depending on the culture where the sample is based. Lastly, the method used for this research can be a limitation as well. To collect the data a convenience sampling method was used. Convenience sampling method was used as it is quick, convenient and less expensive and with the time constraints this was the best fit method for this research. However, the data from convenience sampling method cannot be generalized to represent the entrepreneurial intention of youth across different countries.

\section{References}

Abebe, M. (2012). Social and institutional predictors of entrepreneurial career intention: evidence from Hispanic adults in the U.S. J. Enterprising Culture, 20(01), 1-23.

Almobaireek, W. \& Manolova, T. (2012). Who wants to be an entrepreneur? Entrepreneurial intentions among Saudi university students. African Journal of Business Management, 6(11).

Altinay, L., Madanoglu, M., Daniele, R. \& Lashley, C. (2012). The influence of family tradition and psychological traits on entrepreneurial intention. International Journal of Hospitality Management, 31(2), 489-499.

Anees, S. (2014). Maldivian population increases by 1.56 percent. Haveeru. [online] Available at: http://www.haveeru.com.mv/census_2014/57525 [Accessed 9 May 2015].

Baporikar, N. (2014). Youth Entrepreneurship in Indian Scenario. International Journal of Asian Business and Information Management, 5(2), 74-84.

Baumol, W. J. (1990). Entrepreneurship: productive, unproductive and destructive. Journal of Political Economy, 98, 893-921.

Beaugrand, P. (2004). And Schumpeter Said, This is How Thou Shalt Grow: Further Quest for Economic Growth in Poor Countries. IMF Working Papers, 04(40), 1.

Dash, M. \& Kaur, K. (2012). Youth entrepreneurship as a way of boosting Indian economic competitiveness. International Review of Management and Marketing, 2(1), 10-21. 
Delanoë, S. (2013). From intention to start-up: The effect of professional support. Journal of Small Business and Enterprise Development, 20(2), 383-398.

Dinis, A., do Paço, A., Ferreira, J., Raposo, M. \& Gouveia Rodrigues, R. (2013). Psychological characteristics and entrepreneurial intentions among secondary students. Education + Training, 55(8/9), 763-780.

Eijdenberg, E. \& Masurel, E. (2013). Entrepreneurial motivation in a least developed country: Push factors and pull factors among MSEs in Uganda. J. Enterprising Culture, 21(01), 19-43.

Engle, R., Schlaegel, C. \& Delanoe, S. (2011). The Role of Social Influence, Culture, and Gender on Entrepreneurial Intent. Journal of Small Business and Entrepreneurship, [online] 24(4), 471-492. Available at: http://web.a.ebscohost.com/ehost/pdfviewer/pdfviewer?sid=f5ac2e7e-795c-4270bfe2-c6d72c001c84\%40sessionmgr4001\&vid=0\&hid=4204 [Accessed 12 Nov. 2014].

Engle, R., Dimitriadi, N., Gavidia, J., Schlaegel, C., Delanoe, S., Alvarado, I., He, X., Baume, S. \& Wolff, B. (2010). Entrepreneurial Intent: A Twelve Country Evaluation of Ajzen's Model of Planned Behavior. International Journal of Entrepreneurial Behaviour and Research 16(1), 35-57.

Frank, A. (2007). Entrepreneurship and enterprise skills: A missing element of planning education? Planning Practice and Research, 22(4), 635-648.

Getset.mv. (2015). getset. [Online]. 2015. Available from: http://getset.mv/en/about.php. [Accessed: 2 October 2015].

Gürol, Y. \& Atsan, N. (2006). Entrepreneurial characteristics amongst university students. Education + Training, 48(1), 25-38.

Global Entrepreneurship Monitor. (2014). Global Report. [online] Babson College. Available at: http://www.gemconsortium.org/docs/download/3616[Accessed 7 May 2015].

Gurel, E., Altinay, L. \& Daniele, R. (2010). Tourism students' entrepreneurial intentions. Annals of Tourism Research, 37(3), 646-669.

Hair, J. F., Black, W. C., Babin, B. J. \& Anderson, R. E. (2009). Multivariate data analysis, (7th ed.)Prentice Hall, Upper Saddle River.

Henderson, R. \& Robertson, M. (2000). Who wants to be an entrepreneur? Young adult attitudes to entrepreneurship as a career. Career Dev Int, 5(6), 279-287.

Heuer, A. \& Kolvereid, L. (2014). Education in entrepreneurship and the Theory of Planned Behaviour. Euro J of Training and Dev, 38(6), 506-523.

Ibrahim, A. \& Soufani, K. (2002). Entrepreneurship education and training in Canada: a critical assessment. Education + Training, 44(8/9), 421-430.

Keat, O., Selvarajah, C. \& Meyer, D. (2011). Inclination towards entrepreneurship among university students. International Journal of Business and Social Science, 2(4).

Koe, W., Sa'ari, J., Majid, I. \& Ismail, K. (2012). Determinants of Entrepreneurial Intention among Millennial Generation. Procedia - Social and Behavioral Sciences, 40, 197-208.

Krueger, N. (2008). Entrepreneurial Resilience: Real \& Perceived Barriers to Implementing Entrepreneurial Intentions. Available at SSRN Journal 1155269.

Levesque, M., Shepherd, D. A. \& Douglas, E. J. (2002). Employment or self-employment? A dynamic utilitymaximizing model. Journal of Business Venturing, 17(3), 189-210.

Liñán, F., Urbano, D. \& Guerrero, M. (2011). Regional variations in entrepreneurial cognitions: Start-up intentions of university students in Spain. Entrepreneurship \& Regional Development, 23(3-4), 187215.

Luthje, C. \& Frankle, N. (2003). The 'making' of an entrepreneur: testing a model of entrepreneurial intent among engineering students at MIT. R\&D Management, 33(2), 135-147.

Mitchell, R. K. (2002). Are entrepreneurs born or made? Characteristic V. cognitive theories of new venture creation. Texas Tech University. Available: https://www.ronaldmitchell.org/publications/MitchellEIX\%20NAT\%20V.\%20NURT-prepub.pdf

Mitra, J., Abubakar, Y. \& Sagagi, M. (2011). Knowledge creation and human capital for development: the role of graduate entrepreneurship. Education + Training, 53(5), 462-479.

Mobaraki, M. H. \& Zare, Y. B. (2012). Designing pattern of entrepreneurial self-efficacy on entrepreneurial intention. Information Management and Business Review, 4(8), 428-433.

Mueller, S. \& Thomas, A. (2001). Culture and entrepreneurial potential. Journal of Business Venturing, 16(1), 51-75.

Naish, A. (2014). President Yameen launches MVR200 million 'Maldives Youth Entrepreneurship Programme'. MINIVAN NEWS. [online] Available at: http://minivannews.com/politics/president- 
yameen-launches-mvr200-million-maldives-youth-entrepreneurship-programme-

91106\#sthash.qv7w1yC4.dpbs [Accessed 9 May 2015].

National Bureau of Statistics. (2015). Population and housing census 2014. [Online]. Male': Ministry of Finance and Treasury Republic of Maldives. Available from: http://www.planning.gov.mv/census/census\%202014/CensusPreliminary/PreliminaryResult04Mar2015.pdf. [Accessed: 1 October 2015].

Nunnally, J. (1978). Psychometric Theory. New York: McGraw-Hill.

Praag, C. M. \& Cramer, J. S. (2001). The roots of entrepreneurship and labor demand: individual ability and low risk. Economica, 68(269), 45-62.

Quandl, (2015). Maldives - Unemployment Data - Data from Quandl. [online] Available at: https://www.quandl.com/collections/maldives/maldives-unemployment [Accessed 9 May 2015].

Schoof, U. (2006). Stimulating Youth Entrepreneurship: Barriers and incentives to enterprise start-ups by young people. [online] International Labor Organization. Available at: http://www.ilo.org/youthmakingithappen/PDF/WP76-2006-Rev.pdf [Accessed 05 May. 2015].

Schwarz, E., Wdowiak, M., Almerâe?Jarz, D. \& Breitenecker, R. (2009). The effects of attitudes and perceived environment conditions on students' entrepreneurial intent. Education + Training, 51(4), 272-291.

Sekaran, U., Robert, Y. C. \& Brian, L. D. (2001). Applied Business Research. Australia: John Wiley and Sons, Inc.

Sekaran, U. \& Bougie, R. (2010). Research methods for business. 5th ed. Chichester: Wiley.

Shane, S., Locke, E. A. \& Collins, C. J. (2012). Entrepreneurial motivation. Human Resource Management Review, 13(2), 257-279.

Solesvik, M. (2013). Entrepreneurial motivations and intentions: investigating the role of education major. Education + Training, 55(3), 253-271.

Solesvik, M., Westhead P. \& Matlay, H. (2014). Cultural factors and entrepreneurial intention. Education + Training, 56(8/9), 680 - 696

Noel, T. (1998). Effects of entrepreneurial education on intent to open a business: An exploratory study. Journal of Entrepreneurship Education, 5, 3-13.

Stewart, W. H., Carland, J. C., Carland, J. W., Watson, W. E. \& Sweo, R. (2003). Entrepreneurial dispositions and goal orientations: a comparative exploration of United States and Russian entrepreneurs. Journal of Small Business Management, 41(1), 27-46.

Souitaris, V., Zerbinati, S. \& Al-Laham, A. (2007). Do entrepreneurship programmes raise entrepreneurial intention of science and engineering students? The effect of learning, inspiration and resources. Journal of Business Venturing, 22(4), 566-591.

Tabachnick, B. \& Fidell, L. (2001). Using multivariate statistics. 4th Ed. Boston: Allyn \& Bacon.

Thompson, E.R. (2009). Individual entrepreneurial intent: construct clarification and development of an internationally reliable metric. Entrepreneurship: Theory and Practice, 33(3), 669-694.

Turker, D. \& Sonmez Selcuk, S. (2009). Which factors affect entrepreneurial intention of university students? Jnl Euro Industrial Training, 33(2), 142-159.

Utsch, A. \& Rauch, A. (2000). Innovativeness and initiative as mediators between achievement orientation and venture performance. European Journal of Work and Organizational Psychology, 9(1), 45-62.

Vaillant, Y. \& Lafuente, E. (2007). Do different institutional frameworks condition the influence of local fear of failure and entrepreneurial examples over entrepreneurial activity? Entrepreneurship \& Regional Development, 19(4), 313-337.

Villarino, M. (2015). In Maldives, a country-led youth entrepreneurship movement blooms | Devex. [online] Devex.com. Available at: https://www.devex.com/news/in-maldives-a-country-led-youthentrepreneurship-movement-blooms-85602 [Accessed 9 May 2015].

Wang, C. \& Wong, P. (2004). Entrepreneurial interest of university students in Singapore. Technovation, 24(2), 163-172.

Wilson, G. (2007).Knowledge, innovation and re-inventing technical assistance for development. Progress in Development Studies, (7), 183-199.

Wilson, F., Kickul, J. \& Marlino, D. (2007). Gender, entrepreneurial self-efficacy, and entrepreneurial career intentions: Implications of entrepreneurship education. Entrepreneurship: Theory and Practice, 31(3), 387- 406.

World Economic Forum. (2009). Global Education Initiative Annual Report. [online] Available at: http://www.weforum.org/pdf/GEI/GEI_Annual_Report_2009.pdf [Accessed 12 May 2015]. 